\title{
THE
}

1996

\section{Clarithromycin Does Not Affect Phosphorylation of Zidovudine In Vitro}

Khurram Z. Rana

University of Rhode Island

W. Darnowski

Andy H. Strayer

University of Rhode Island

Michael N. Dudley

University of Rhode Island

Follow this and additional works at: https://digitalcommons.uri.edu/php_facpubs

Terms of Use

All rights reserved under copyright.

\section{Citation/Publisher Attribution}

Rana, K. Z., Darnowski, J. W., Strayer, A. H., \& Dudley, M. N. (1996). Clarithromycin Does Not Affect Phosphorylation of Zidovudine In Vitro. Antimicrobial Agents and Chemotherapy, 40(8), 1945-1947. doi: 10.1128/AAC.40.8.1945

Available at: http://dx.doi.org/10.1128/AAC.40.8.1945

This Article is brought to you for free and open access by the Pharmacy Practice at DigitalCommons@URI. It has been accepted for inclusion in Pharmacy Practice Faculty Publications by an authorized administrator of DigitalCommons@URI.For more information, please contact digitalcommons-group@uri.edu. 


\title{
Clarithromycin Does Not Affect Phosphorylation of Zidovudine In Vitro
}

\author{
KHURRAM Z. RANA, ${ }^{1,2}$ JAMES W. DARNOWSKI, ${ }^{2}$ ANDY H. STRAYER,,${ }^{1,2} \dagger$ \\ AND MICHAEL N. DUDLEY ${ }^{1,2 *}$ \\ Antiinfective Pharmacology Research Unit, University of Rhode Island College of Pharmacy, ${ }^{1}$ and \\ Roger Williams Medical Center, ${ }^{2}$ Providence, Rhode Island
}

Received 19 October 1995/Returned for modification 7 February 1996/Accepted 1 May 1996

\begin{abstract}
Zidovudine (ZDV) and clarithromycin (CLR) are often used simultaneously in the management of patients with AIDS. While pharmacokinetic studies show decreased absorption of ZDV when it is administered with CLR, it is unknown if CLR affects the intracellular metabolism of ZDV. We investigated the effects of CLR on the intracellular metabolism of ZDV in vitro. CEM-T4 cells were coincubated with $1 \mu \mathrm{M}$ ZDV $\left(\left[{ }^{3} \mathrm{H}\right] \mathrm{ZDV}, 3\right.$ $\mu \mathrm{Ci} / \mathrm{ml}$ ) either alone or with 1 or $10 \mu \mathrm{M}$ CLR. Cells were also grown in the presence of CLR for $48 \mathrm{~h}$ prior to exposure to ZDV. Samples were analyzed for mono-, di-, and triphosphate metabolites of $\left[{ }^{3} \mathrm{H}\right] \mathrm{ZDV}$ by high-performance liquid chromatography separation and radiochemical detection. There were no significant differences in levels of intracellular metabolites of $\mathrm{ZDV}$ following exposure to $\mathrm{ZDV}$, either alone or with 1 or $10 \mu M$ CLR and under both coincubated and preincubated conditions. These results show that treatment with CLR does not alter the formation of phosphorylated metabolites of ZDV in this cell line.
\end{abstract}

The progression of disease in individuals infected with the human immunodeficiency virus to AIDS has resulted in the use of several chemotherapeutic agents to treat the various opportunistic infections which arise. Zidovudine (ZDV), a first-line agent used to treat human immunodeficiency virus infection, and clarithromycin (CLR) are often used simultaneously in the management of patients infected with human immunodeficiency virus when CD4 cell counts drop below 200 cells per $\mathrm{mm}^{3}$ because of the emergence of the Mycobacterium avium-M. intracellulare complex.

ZDV suppression of viral replication is dependent upon passage of ZDV across cell membranes by both passive diffusion and facilitated processes. Once ZDV is inside the cell, activation of the drug to the active triphosphate (TP) moiety is generated by host cellular kinases $(4,14)$. ZDV is phosphorylated to the monophosphate (MP) derivative by thymidine kinase and then further phosphorylated by thymidylate kinase to the diphosphate (DP) metabolite. The final step to the TP form is not clear, but the enzyme involved is presumed to be a DP kinase. The conversion from the DP form to the active TP moiety enables the drug to become incorporated into elongating viral DNA chains and act as a chain terminator of reverse transcriptase-mediated DNA synthesis. Other factors that influence ZDV TP production are competition with thymidine, feedback inhibitors of the pathway, downregulation of enzymes, stage of disease, and various drugs which interfere with thymidine synthesis.

CLR, a macrolide antibiotic, is active against a variety of organisms including Mycobacterium avium, unlike erythromycin, which has poor activity against mycobacteria. CLR is an effective inhibitor of RNA-dependent protein synthesis of susceptible bacteria (8), and a notable feature is its high penetration into tissue and leukocytes (9).

\footnotetext{
* Corresponding author. Mailing address: Antiinfective Pharmacology Research Unit, Roger Williams Medical Center, 825 Chalkstone Ave., Providence, RI 02908. Phone: (401) 456-2261. Fax: (401) 4566590 .

$\dagger$ Present address: University of Kansas, School of Pharmacy, Lawrence, KS 66048.
}

Initial evidence from pharmacokinetic studies suggests that CLR interferes with ZDV absorption, leading to slightly decreased maximum concentrations in plasma and areas under the concentration-time curves of ZDV; it has been suggested that this interaction occurs only when the drugs are administered concurrently $(5,10,11)$. However, a study with children found that serum CLR concentrations were unaffected by either ZDV or didanosine (6). Since these previous studies addressed only drug pharmacokinetics in serum, it is unknown whether CLR might also affect the intracellular metabolism of ZDV. Mechanisms that could be affected by the macrolide could include the alteration of the synthesis of key enzymes known to activate ZDV and the passage of ZDV into cells. This study investigated the effects of CLR on the intracellular metabolism of $\mathrm{ZDV}$ in vitro.

(This work was presented in part at the 34th Interscience Conference on Antimicrobial Agents and Chemotherapy, Orlando, Fla., October 1994 [11a]).

ZDV (Burroughs Wellcome Co., Research Triangle Park, N.C.) and CLR (Abbott Laboratories, Abbott Park, Ill.) were dissolved in media, sterile filtered, and diluted to the appropriate concentrations in modified RPMI 1640 media containing L-glutamine, fetal bovine serum, and $25 \mathrm{mM}$ HEPES $(N$ 2-hydroxyethylpiperazine- $N^{\prime}$-2-ethanesulfonic acid) buffer (Life Technologies, Grand Island, N.Y.).

Continuous cultures of CEM-T4 lymphocytes (National Institutes of Health AIDS Research and Reagent Program, Ogden Bioservices Corp., Rockville, Md.) grown in media supplemented with $10 \%$ fetal bovine serum were used in all studies. The doubling time of cells grown in a humidified incubator at $37^{\circ} \mathrm{C}$ in a $5 \% \mathrm{CO}_{2}$ atmosphere was approximately $24 \mathrm{~h}$. CEM-T4 cell growth and cell viability over 5 days were not affected by the two drugs, either alone or in combination; thus, no cytotoxicity was observed. Cell counts and viability were determined daily with trypan blue exclusion. All experiments were performed in duplicate.

Five to ten million CEM-T4 cells were coincubated for $24 \mathrm{~h}$ with $1 \mu \mathrm{M}$ ZDV $\left(\left[{ }^{3} \mathrm{H}\right] \mathrm{ZDV}, 3 \mu \mathrm{Ci} / \mathrm{ml}\right.$ [Moravek Biochemicals, Brea, Calif.]) alone or with 1 or $10 \mu \mathrm{M}$ CLR in a final volume of $10 \mathrm{ml}$ of modified RPMI 1640 medium. Cells were also 


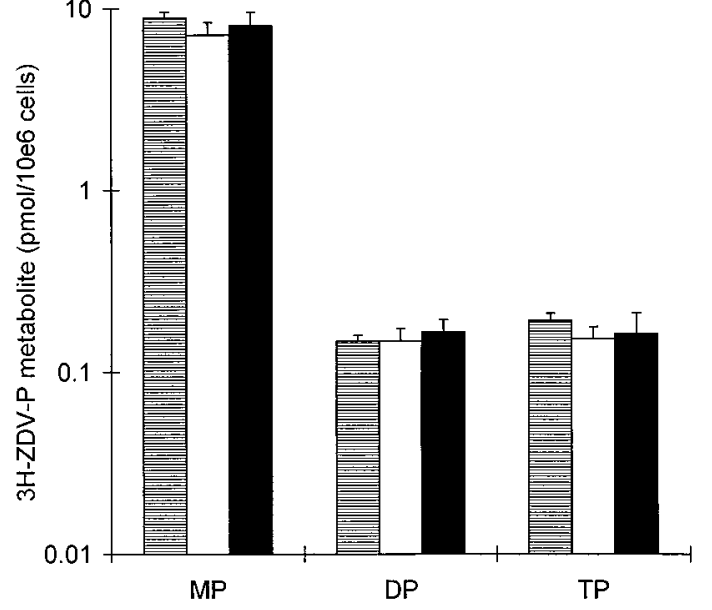

FIG. 1. Intracellular phosphorylated metabolites of ZDV after incubation with $1 \mu \mathrm{M}$ ZDV alone (hatched bars), after incubation with ZDV and $1 \mu \mathrm{M}$ CLR (white bars), and after $48 \mathrm{~h}$ of preincubation with $1 \mu \mathrm{M}$ CLR (black bars). Data are means \pm standard errors of the means $(n=3)$.

grown in the presence of CLR for $48 \mathrm{~h}$; this was followed by addition of ZDV and incubation for an additional $24 \mathrm{~h}$. After the 24-h incubation with ZDV, cells were centrifuged and the medium was removed. The cells were then washed twice with $10 \mathrm{ml}$ of phosphate-buffered saline (PBS). Phosphorylated metabolites were extracted with $200 \mu$ l of $0.2 \mathrm{~N}$ perchloric acid for $30 \mathrm{~s}$. After centrifuging, supernatants were transferred to clean tubes, neutralized with equivalent amounts of sodium hydroxide, and frozen until the assay. All experiments were performed in triplicate.

Samples were analyzed for $\left[{ }^{3} \mathrm{H}\right] \mathrm{ZDV}$ MP, DP, and TP metabolites by high-performance liquid chromatography separation and radiochemical detection (12). The phosphorylated metabolites were separated with an anion-exchange column (Whatman SAX-10, $4.6 \mathrm{~mm}$ by $25.0 \mathrm{~cm}$ ) and eluted from the column at $1 \mathrm{ml} / \mathrm{min}$ by using a $45-\mathrm{min}$ linear gradient of $10 \mathrm{mM}$ $\mathrm{NaH}_{2} \mathrm{PO}_{4}\left(\mathrm{pH} \mathrm{3.5)}\right.$ to $500 \mathrm{mM} \mathrm{NaH}{ }_{2} \mathrm{PO}_{4}-500 \mathrm{mM} \mathrm{KCl}(\mathrm{pH}$ 3.5). The column eluent was monitored by UV detection at 254 $\mathrm{nm}$ and by a Radiomatic scintillation detector (Rainin Instrument Co., Medford, Mass.) connected in-line. The column retention times for ZDV MP, ZDV DP, and ZDV TP were 10, 25 , and $50 \mathrm{~min}$, respectively. The quantity of each ZDV metabolite was represented as picomoles per $10^{6}$ cells, and the calculation was based on the integrated peak area of the radiochromatogram for each metabolite, the specific activity of the radiolabelled drug, and the number of cells analyzed.

$\left[{ }^{3} \mathrm{H}\right] \mathrm{TTP}$ was used as a marker for recovery of ZDV TP and was added $(1 \mu \mathrm{Ci})$ to drug-free samples after removal of the final wash with PBS. An aliquot of supernatant was quantitated for radioactivity by liquid scintillation, as was the pellet. Less than $5 \%$ of total radioactivity was lost to the pellet. The interday amount recovered in the supernatant was $73 \%$, with an interday precision of $7.6 \%$.

Differences in the phosphorylated metabolites in the different groups were assessed with one-way analysis of variance in which an $\alpha$ value of 0.05 was used to define significance.

The most abundant intracellular ZDV metabolite in CEM-T4 cells after $24 \mathrm{~h}$ was MP under all conditions; DP and TP were formed in much smaller quantities. When cells were incubated with $1 \mu \mathrm{M}$ CLR, the amounts of phosphorylated ZDV metabolites generated were similar to the amounts generated by cells not incubated with CLR (Fig. 1). The amounts
TABLE 1. Proportion of ZDV as $\mathrm{TP}^{a}$

\begin{tabular}{lcc}
\hline \multicolumn{1}{c}{$\begin{array}{c}\text { Incubation condition } \\
\text { of cells }\end{array}$} & $\begin{array}{c}\% \text { of total } \\
{\left[{ }^{3} \mathrm{H}\right] \mathrm{ZDV} \text { as TP }}\end{array}$ & MP/TP ratio \\
\hline ZDV alone & $2.2 \pm 0.2$ & $47.1 \pm 3.8$ \\
& & \\
ZDV with 1 $\mu \mathrm{M}$ CLR & $2.1 \pm 0.04$ & $47.2 \pm 0.9$ \\
$\quad$ Coincubated & $2.0 \pm 0.2$ & $51.2 \pm 6.8$ \\
Preincubated $48 \mathrm{~h}$ & \\
ZDV with $10 \mu \mathrm{M} \mathrm{CLR}$ & $2.9 \pm 0.7$ & $37.1 \pm 6.9$ \\
$\quad$ Coincubated & $2.0 \pm 0.2$ & $51.1 \pm 5.1$ \\
$\quad$ Preincubated $48 \mathrm{~h}$ &
\end{tabular}

of intracellular metabolites were also not different when cells were coincubated or preincubated with $10 \mu \mathrm{M}$ CLR. The proportion represented by TP, the most important derivative, was similar under all conditions, as were the ratios of MP to TP (Table 1). The variation in MP/TP ratios can be explained by the variation in the MP metabolite.

The concentrations of drugs tested in this study were similar to those achieved clinically. Following an oral 200-mg dose of ZDV in humans, maximum concentrations in plasma of 3 to 4 $\mu \mathrm{M}$ are achieved (13). Concentrations of ZDV in plasma fall rapidly to less than $1 \mu \mathrm{M}$ over the dosing interval of $8 \mathrm{~h}$. Maximum concentrations in plasma of $2.7 \mu \mathrm{M}(2.1 \mu \mathrm{g} / \mathrm{ml})$ were achieved for CLR after an oral 500-mg dose (3). Therefore, experimental conditions of 1 and $10 \mu \mathrm{M}$ CLR represented concentrations observed after single and multiple oral doses in humans.

All newer macrolides are known to accumulate in tissue, thereby achieving higher concentrations than those in serum. The intracellular concentration of CLR has been shown to be 9-fold to 16-fold higher than the extracellular concentration in human neutrophils and polymorphonuclear leukocytes $(1,7)$. The results from this study show no changes in the ability of this cell line to phosphorylate ZDV when CLR was present. The presence of DP and TP in much smaller quantities is reflective of a rate-limiting conversion from MP to DP, which is consistent with quantities reported in other studies $(2,4)$.

The significance of these results appears to be that no routine drug adjustment is warranted in the clinical setting. Potential interactions could still occur between other antiretroviral agents and CLR. In addition, other macrolides may affect the intracellular metabolism of ZDV and the other antiretroviral agents. Further studies may be needed to investigate these potential interactions.

This work was supported in part by Abbott Laboratories.

\section{REFERENCES}

1. Anderson, R., G. Joone, and C. E. J. Van Rensburg. 1988. An in-vitro evaluation of the cellular uptake and intraphagocytic bioactivity of clarithromycin (A-56268, TE-031), a new macrolide antimicrobial agent. J. Antimicrob. Chemother. 22:923-933.

2. Avramis, V. I., W. Markson, R. L. Jackson, and E. Gomperts. 1989. Biochemical pharmacology of zidovudine in human T-lymphoblastoid cells (CEM). AIDS 3:417-422.

3. Chu, S., D. S. Wilson, R. L. Deaton, A. V. Mackenthun, C. N. Eason, and J. H. Cavanaugh. 1993. Single- and multiple-dose pharmacokinetics of clarithromycin, a new macrolide antimicrobial. J. Clin. Pharmacol. 33:719-726.

4. Furman, P. A., J. A. Fyfe, M. H. St. Clair, K. Weinhold, J. L. Rideout, G. A Freeman, S. Nusinoff-Lehrman, D. P. Bolognesi, S. Broder, H. Mitsuya, and D. W. Barry. 1986. Phosphorylation of $3^{\prime}$-azido-3'-deoxythymidine and selective interaction of the $5^{\prime}$-triphosphate with human immunodeficiency virus reverse transcriptase. Proc. Natl. Acad. Sci. USA 83:8333-8337.

5. Gustavson, L. E., S. Chu, A. Mackenthun, S. D. Gupta, and J. C. Craft. 1991. 
Drug interaction between clarithromycin and oral zidovudine in HIV-1 infected patients. Clin. Pharmacol. Ther. 53:163.

6. Husson, R. N., L. A. Ross, S. Sandelli, C. B. Inderlied, D. Venzon, L. L. Lewis, L. Woods, P. S. Conville, F. G. Witebsky, and P. A. Pizzo. 1994. Orally administered clarithromycin for the treatment of systemic Mycobacterium avium complex infection in children with acquired immunodeficiency syndrome. J. Pediatr. 124:807-814.

7. Ishiguro, M., H. Koga, S. Kohno, T. Hayashi, K. Yamaguchi, and M. Hirota. 1989. Penetration of macrolides into human polymorphonuclear leucocytes. J. Antimicrob. Chemother. 24:719-729.

8. Neu, H. C. 1991. The development of macrolides: clarithromycin in perspective. J. Antimicrob. Chemother. 27(Suppl. A):1-9.

9. Peters, D. H., and S. P. Clissold. 1992. Clarithromycin. A review of its antimicrobial activity, pharmacokinetic properties and therapeutic potential. Drugs 44:117-164.

10. Petty, B., M. Polis, S. Haneiwich, M. Dellerson, J. C. Craft, and R. Chaisson. 1992. Pharmacokinetic assessment of clarithromycin plus zidovudine in HIV patients, abstr. 24, p. 114. In Program and abstracts of the 32nd Interscience Conference on Antimicrobial Agents and Chemotherapy. American Society for Microbiology, Washington, D.C.

11. Polis, M. A., S. Haneiwich, J. A. Kovacs, R. T. Davey, R. E. Walker, J. Falloon, G. Galetto, J. Metcalf, M. Amantea, M. Dellerson, S. Schlager, C. Craft, B. Petty, H. C. Lane, and H. Masur. 1991. Dose escalation study to determine the safety, maximally tolerated dose (MTD), and pharmacokinetics of clarithromycin (clari) with zidovudine (zdv) in HIV-infected persons, abstr. 238, p. 138. In Program and abstracts of the 31st Interscience Conference on Antimicrobial Agents and Chemotherapy. American Society for Microbiology, Washington, D.C

11a.Rana, K. Z., J. W. Darnowski, D. A. Copeland, A. H. Strayer, P. E. Pivarnik, and M. N. Dudley. 1994. Clarithromycin (CLR) does not affect intracellular concentrations of phosphorylated metabolites of zidovudine (ZDV), abstr. I197, p. 211. In Abstracts of the 34th Interscience Conference on Antimicrobial Agents and Chemotherapy. American Society for Microbiology, Washington, D.C.

12. Tosi, P., P. Calabresi, F. A. Goulette, C. A. Renaud, and J. W. Darnowski. 1992. Azidothymidine-induced cytotoxicity and incorporation into DNA in the human colon tumor cell line HCT-8 is enhanced by methotrexate in vitro and in vivo. Cancer Res. 52:4069-4073.

13. Unadkat, J. D., A. C. Collier, S. S. Crosby, D. Cummings, K. E. Opheim, and L. Corey. 1990. Pharmacokinetics of oral zidovudine (azidothymidine) in patients with AIDS when administered with and without a high-fat meal. AIDS 4:229-232.

14. Yarchoan, R., H. Mitsuya, C. E. Myers, and S. Broder. 1989. Clinical pharmacology of $3^{\prime}$-azido-2',3'-dideoxythymidine (zidovudine) and related dideoxynucleosides. N. Engl. J. Med. 321:726-737. 